NBER WORKING PAPER SERIES

\title{
AMERICAN REGIONALISM AND \\ GLOBAL FREE TRADE
}

Edward E. Leamer

Working Paper No. 4753

\section{NATIONAL BUREAU OF ECONOMIC RESEARCH 1050 Massachusetts Avenue \\ Cambridge, MA 02138 \\ May 1994}

Support from NSF grant SES-9209845 and from the Center for Pacific Rim Studies is gratefully acknowledged. Very helpful comments were provided by Femando Losada. This paper is part of NBER's research program in International Trade and Investment. Any opinions expressed are those of the author and not those of the National Bureau of Economic Research. 


\title{
AMERICAN REGIONALISM AND \\ GLOBAL FREE TRADE
}

\begin{abstract}
A free trade agreement supports global free trade since trade barriers tend to divert trade in favor of members, but not reduce imports. The term: "mutual assured deterrence" is used to refer to a regional free trade association that has the feature that no member can gain individually from the imposition of a barrier against a non-member. Mutual assured deterrence is shown to be possible for a surprisingly rich set of partners.

A customs union is compatible with global free trade if the vast majority of trade takes place naturally within the confines of the association. A customs union that is likely to have this property would combine countries to form a nearly exact economic replica of the globe.

The economic combination of Mexico and the United States doesn't form a replica of the global economy because, compared with Asia, North America has relatively high capital per worker even after adding the Mexican workforce. However, NAFTA does seem to have the property of mutual assured deterrence, and may for that reason amount to a commitment to global free trade as well as regional free trade.
\end{abstract}

Edward E. Leamer

Anderson Graduate School of Management

UCLA

Los Angeles, CA 90024

and NBER 


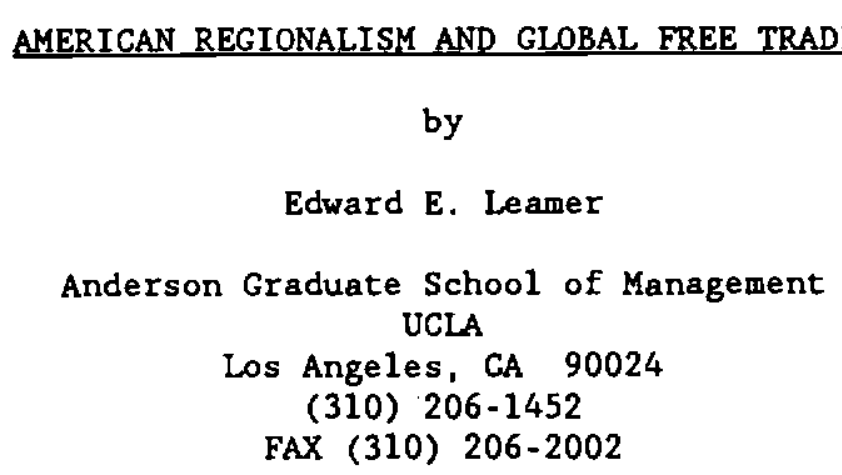

May 11, 1994

\section{INTRODUCTION}

There is an eerie sense of deja vu that accompanies the splitting of the world into three regional trading blocs organized around the principal protagonists of a drama of another sort: the United States, Japan and Germany.

But regionalism can be compatible with globalism. Indeed regionalism may be the only route by which a global economy can be achleved because of the political constraints and complexities that make global trade agreements 1ike GATT difficult to craft and even more difficult to enforce.

Regionalism implies globalism when regional trading associations are formed that minimize the incentives for erecting barriers against non-members. Krugman(1991a) observes that if customs unions seek to exploit monopoly power in their external markets then it is undesirable to have either too many or too few customs unions. As the number of customs unions (including separate countries) diminishes, each gets 
larger and the degree of monopoly power in the external markets increases, as do tariff levels. But also as the number of customs unions diminishes, more and more trade is internal to the blocs and not subject to barriers. These offsetting forces can produce a complicated relationship between world welfare and the number of customs unions, but Krugman offers a provocative example in which the worst number is three! Krugman(1991b) has a different tone, emphasizing the substantial effect of distance on trade patterns. If most trade is naturally among close neighbors, and if associations are formed on a regional basis, then these associations may protect most of world trade from government interference.

This paper presents another argument why a free trade agreement may be very supportive of globalism. A free trade agreement allows members to select their own barriers against non-members. Barriers that are raised by one country alone may only divert trade away from nonmembers toward other members but not protect the market of the country that erects the barrier. Such a country would have a reduced incentive to impose barriers, whether the barriers are intended to exploit external monopoly power or to redistribute income.

The two-good model of Vanek(1965) captures the spirit of the deterrence idea being discussed here. ${ }^{2}$ Suppose that $C$ is a large country that determines the world terms of trade, that B is a smaller version of $C$ with the same autarchic price ratios, and that $A$ has different factor supplies and different autarchic price ratios. If A and $B$ form a free trade agreement, and A lmposes barriers against imports from C, A's trade is diverted away from $C$ in favor of $B$. This 2 See Corden(1984) for references and a review of the literature on twogood and three-good customs unions. 
benefits B, the country that does not trade with the outsider, at the expense of $A$, the country Imposing the barrlers. The benefits to $A$ in terms of Income redistribution may be worth the cost, even with this trade diversion effect. However, since the costs are higher with the free trade agreement than without, we may conclude that the barriers against $C$ Imposed by $A$ wll be less if the free trade agreement is in place.

More explicitly, if there is a free trade agreement between Mexico and the United States, barrlers to Imports of apparel, for example, Into the United States from Asla might primarily divert trade from Asla in favor of Mexico but have 11ttle protective effect in the U.S. marketplace. In that event, the free trade agreement between the United States and Mexico greatly reduces the benefits to U.S. apparel manufacturers that come from trade barrlers erected agalnst Aslan products and these barriers are much less l1kely to be erected. After all, why should U.S. manufacturers go to all the trouble to petition for protection from Aslan products, when all that protection does is to increase competition from Mexico? Generally, U.S. barrlers against Aslan products are likely to be lower with the North American Free Trade Agreement than without. Offsetting that effect from the Aslan perspective is the preferential treatment given to Mexican products.

I propose to borrow from another 11terature the term: "mutual assured deterrence" to refer to a reglonal free trade association that has the feature that no member can gain individually from the imposition of a barrier agalnst a non-member. You may suspect that mutual assured deterrence is very difficult to achleve, but your thinking probably does not take Into account the fact that a barrier erected by one member 
creates an incentive for other members to ship all of their production to the protected, high-priced marketplace, and to import from nonmembers low-priced goods for consumption purposes. When this effect is properly taken into account, mutual assured deterrence is posstble for a surprisingly rich set of partners.

If the regional association is a customs union, with common external barriers, the concept of mutual assured deterrence is inapplicable. For customs unions, two arguments are presented why regional associations may promote globalism. One possibility is that the customs union is formed in a way such that the vast majority of trade takes place naturally within the confines of the association. Then there is very little reason to erect barriers against non-members because the barriers would have 1ittle effect. A customs union that is likely to have this property would combine countries to form a nearly exact economic replica of the globe, thereby eliminating most of the reason for external trade. Incidentally, as Krugman(1991b) observes, the regional aspect of "regionalism" is an important feature since most trade naturally takes place over falrly short distances. A customs union between the United States and Mexico is much more likely for this reason to be supportive of globalism than is an association between the United States and Russia, since the later will encompass a much smaller share of the members trade.

Another reason why a customs union may be less likely to erect barriers against non-members is that members may have conflicting interests that tend to offset each other. In the EEC, apparel sold in the United Kingdom will come from Portugal or from Asia but will not be produced much in the U.K. The EEC debate over the erection of barriers 
against Asian apparel thus pits U.K. consumers against Portuguese producers, which may be more of a standoff than a match between U.K. consumers and U.K. producers.

Two Intellectual tools are helpful in elucldating these Ideas. First there is the Stolper-Samuelson theorem which maps changes in goods prices induced by trade barriers into changes in factor earnings. The traditional Stolper-Samuelson theorem is not perfectly sulted to the study of regional associations because it is based on an implicit assumption that earnings come entirely from the supply of labor services or entirely from the supply of capital earnings. It is not difficult to adopt the result to deal with reglons with mixed ownership of capital and labor. Not surprisingly, regions with relatively large supply of labor prefer high prices for labor intensive goods. Reglonal StolperSamuelson theorems are the subject of the next section.

Sections III, IV and $V$ examine reglonal assoclations using several different kinds of economic models including partial equilibrium, onecone Heckscher-OhIIn general equilibrium and multi-cone Heckscher-Ohlin general equilibrium models, with and without internal factor mobllity. It will be shown that if association members are large enough to satisfy the demand for imports from third countries, then the discriminatory barriers are completely ineffective since they divert but do not destroy trade.

After all this heavy-duty economic theory, Section VI wraps up with some emplrical evidence regarding the propused North American Free Trade Agreement. The economic combination of Mexico and the United States doesn't seem to form a replica of the global economy because, compared with Asia, North America has relatively high capital per worker 
even after adding the Mexican workforce. However, Mexico does seem large enough to satisfy a substantial share of U.S. demand for labor Intensive manufactures and for that reason the NAFTA may serve as a major deterrent to the erection of U.S. barriers against Asla.

II. STOLPER-SAMUELSON WITH MIXED OWNERSHIR

The Lerner-Pearce diagram in Figure 1 is a standard graphical setting in which to demonstrate the Stolper-Samuelson Theorem. On this figure are drawn unit-value isoquants for two products. These unitvalue isoquants are combinations of capital and labor that are required to produce a unit value of output. For ease of graphing primarily, these are drawn as right angles indicating that there are no substitution possibilities in either sector. Machinery is assumed to be the capital intensive sector with a fixed capital per worker which is higher than textiles. Also on this diagram is drawn a unit cost line through the corners of the two unit-value isoquants. This is the only unit cost line that is compatible with the production of both goods at zero profits. The equation for this isocost line is I - w L $r K$, where $w$ is the wage rate and $r$ is the capital rental rate. This line accordingly crosses the labor axis at $1 / w$ and the capital axis at $1 / r$, both of which are labelled in the figure.

The Stolper-Samuelson theorem postulates an increase in the price of textiles, for example, and computes the induced changes in the factor earnings. In Figure 1, the increase in the price of textiles shifts the unit-value isoquant for textiles inward to the dotted right-angle, Indicating that it takes less capital and labor to produce a unit value of textiles after the price goes up. This is accompanied by a shift in 
the unit isocost to the dotted line, which can be seen implies a higher wage rate $\left(w^{\prime}>w\right)$ and a lower return on capital. Thus:

The Stolper-Samuelson Theorem: A rise in the price of a product gives rise to an increase in the (real) earnings of the factor used intensively in that product and a reduction in the (real) earnings of the other factor.

The Stolper-Samuelson result implicitly is based on the assumption of pure ownership: An individual either supplies only labor services or only capital services. It is not difficult to amend the result to deal with mixed ownership. The unit cost lines can be interpreted as the combinations of factors that can earn enough to purchase either a unit value of machinery or a unit value of textiles. The solid line unit cost line thus represents combinations of factors that can purchase either a unit of machinery or a unit of textiles at the original prices. Since the price of machinery is unchanged, the initial and final unit cost lines represent ownership needs for the purchase of a like amount of machinery. These two lines have one point in common: the point labelled $M$ where the ownership ratio is equal to the input ratio in machinery. Thus a person who consumed only machinery and who owned a combination of factors that were fust suited to machinery production would be unaffected by this price increase in textiles. If this machinery-consuming individual owned more capital, she could buy less machinery after the price increase in textiles. If this individual owned more labor, then she could buy more machinery after the price change.

Another line is necessary to discuss the factor needs to purchase the original amount textiles because the new unit cost line refers to 
textiles that are sold at higher prices. To determine the ownership needs to purchase the old quantity of textiles it is necessary to draw a line parallel to the new unit cost line through the corner of the old textiles unit value isoquant. This line is labelled "Ownership Needs for Textile Consumption." This line crosses the original unit cost line at the point $T$. Thus a person who consumed only textiles and who owned a combination of factors that were just suited to textile production would be unaffected by this price increase in textiles. If this textlle-consuming individual owned more capital, she could buy less textiles after the price increase. If she owned more labor, then she could buy more textiles.

Incidentally, the Stolper-Samuelson theorem refers to the points where these two consumption lines cross the two axes: If only labor is owned, the price increase in textlles leaves one better off regardless of the consumption good, but relatively better off in machinery consumption than textile consumption.

The following results come straightforwardly from Figure 1: Stolper-Samuelson Theorem with Extreme Ownershlp: If ownership of the factors lies outside the interval between the capital/labor ratios of the two industries, an increase in the price of the labor intensive good increases the real earnings of labor abundant individuals and reduces the real earnings of capital abundant individuals, regardless of the good consumed.

Stolper-Samuelson Theorem with Intermed tate Ownership: If ownership of the factors lies between the intensity ratios in the two industries, then an increase in the price of the labor-intensive good increases the real consumption power in terms of the labor- 
intensive good but lowers the real consumption power in terms of the capital-intensive good.

\section{III, A PARTIAL EQUILIBRIUM MODEL OF A FREE TRADE AGREEMENT}

A second tool for studying regional associations is the partial equilibrium diagram, Figures 2 and 3 , which Indicate the effect of a free trade agreement between the United States and Mexico in a setting in which the United States has an external barrier but Mexico has none. These figures convey the important message that the effect of the FTA on the United States depends critically on the economic size of Mexico. ${ }^{3}$ Figure 2 indicates the effect of a FTA when the form of the U.S. protection is a tariff. In this figure the world price and the U.S. protected price are illustrated with horizontal lines. The downward sloping curve is the U.S. Import demand and the two upward sloping lines are alternative Mexican supply curves. If Mexico is small and has the supply curve close to the vertical axis, then, prior to the establishment of the FTA, Mexican production would be $A B$ and U.S. Import demand would be CE. A portion of the Mexican supply would go to satisfying home demand and, if there is any left over, the rest might find Its way to the U.S. market. After the FTA, all the Mexican output is sold at the high U.S. prices and Mexican demand is satisfled at the world price from third sources. The Mexican supply to the U.S. market increases to $C D$ which crowds out third country exports to the U.S. The total trade diversion is between $C D$ and $C D-A B$, the latter figure applicable if all the Mexican product were sold in the U.S. market prior to the FTA. The facts are that very little of Mexican product is

3 Discussion like this can be found in McCulloch and Pinera(1977) who offer a partial equilibrium treatment of the tariff case. Gardner and K1mbrough(1990) do the general equilibrium case. 
currently sold in the U.S. and the larger figure CD seems applicable. On the other hand, the simple diagram includes no transportation and marketing costs which would encourage home sales and which would preyent all the Mexican product from being sold in the U.S.

If this first supply curve is applicable, then the FTA would not affect the prices at which goods sell inside the United States. But now move the Mexican supply to the right. At some point it will intersect the U.S. demand at the point E where all U.S. Import demand is satisfied from Mexican sources. Further increases in Mexican supply will drive down the U.S. Internal price. If the Mexican supply curve goes through the point F on the U.S. Import demand curve then the world price would prevail in the U.S. markets. Further increases in Mexican supply would not cause further reductions in the U.S. price since Mexican suppliers would not sell at any price lower than the one prevailing in the world market. The dashed line in the lower right of Figure 2 illustrates this case. Total Mexican supply is AG. The amount AF is sold in the U.S. market at world prices and the remainder FG is sold partly at home and partly in third markets. From this figure we derive the following important conclusion: If Mexico is large enough that she can completely satisfy incipient import demand of the U.S. that would cccur at world market prices, then an FTA would completely dismantle U.S, protection,

A substantially different description applies to the quota case illustrated in Figure 3 . Here the quota is assumed to be quantity FG and prices Inside the U.S. market are adjusted so that import supply and Import demand are equalized. This quota level is selected to create an initial equilibrium equivalent to the tariff equilibrium depicted in Figure 2. With the formation of the FTA, the equivalence of the quota 
and tariff breaks down. The smallest amount of Mexican supply supplements the quota-restricted imports and puts downward pressure on U.S. prices. The FTA price can be found in Figure 3 by defining U.S. import demand net of Mexican supply and then selecting a U.S. price that equates net demand to the quota level. This import price is lower than the U.S. protected price, even though Mexico is too small to satisfy total U.S. import demand. Note that by moving the Mexican supply to the right, one may conclude that the U.S. price reverts to the unprotected world market price if Mexican supply is enough to make up the difference between the U.S. Import demand that would occur at the world price and the quota level of imports. In the extreme, If the quota level is zero, then we revert to the tariff conclusion: The world price prevalls if Mexico is large enough to satisfy completely U.S. Import demand at the world market price.

IV. REGIONAL ASSOCIATIONS: ONE CONE HECKSCHER-OHLIN MODEL

The partial equilibrium analysis of the effect of a free trade agreement can be Interestingly introduced into the "one-cone" HeckscherOhlin model deplcted in Figure 4. Thls "one-cone" model uses the assumption that all countries have endowment supplies falling between the capital/labor ratios in the two industries. In this model, a regional association that had a comblned supply of capital and labor with exactly the same capital/labor ratio as the world totals would be a holographic replica of the world's economy and would not need to engage In trade with any non-members, provided of course that taste differences are not a source of trade. Since the autarchic prices of this regional assoctation are the same as the world's prices, there would be no trade external to the assoclation and no effect of trade barriers. If 
barrlers were already in place before the regional assoctation were formed, the barriers might remain, although they would have the effect only of hastening the adjustment to the new equilibrium in which there is substantial trade among the members of the assoctation and very Ifttle trade otherwise. Incidentally, just as openness is not properly measured by trade dependence, globalism is not properly measured by the amount of extra-association trade, which in the case just considered would be zero even if the assoclation were completely open.

\section{A. Customs Union}

If the combined regional factor supply were not a replica of the world's total factor supply, then the reglonal assoclation would have a demand for imports from non-members. The two tools that were discussed in the previous two sections would then become applicable, first the Stolper Samuelson Theorem and then the analysis of trade diversion. If the association is a customs union with common external barriers then the regional stolper Samuelson theorem indicates the conditions under which the trade barriers have the greatest effect on redistributing income between regions, namely when the factor ownership patterns are very different among regions. It seems natural to surmise that disparity in reglonal effects tends to reduce barriers since it encourages regional coaltions in opposition. of course, it is possible that this would work in the opposite way: The greater the regional redistributive effect of the barrier, the more likely that it will be erected.

\section{B. Free Trade Agreement}

If the association is a free trade agreement, barrlers erected by one member against non-members may only divert trade in favor of members 
but have no protective effect. This was discussed using partial equilibrium models in the context of Figures 2 and 3 . Figure 4 is a general equilibrium analog of these two diagrams. Here we have the United States and Mexico both with factor supplies located Inside the cone swept out by the expansion vectors for machinery and for textlles. On this diagram is drawn also a line representing the world's ratio of capital to labor. The vector connecting the U.S. factor supply point with this world factor supply line is the U.S. net imports of factor services. As drawn, the U.S. Is abundant in capital, exports capital services and Imports labor services. This service flow is accomplished by exporting the capital intensive good, machinery, and Importing the labor Intensive good, textiles.

Suppose now that the UnIted States were to Impose trade barrlers against the Imports of textiles from Asia. This would tend to divert textile trade toward Mexico. Is the diversion effect enough to completely undo the U.S. protectionism? The answer is yes if Mexican total supply of textiles is enough to satisfy the U.S. Import demand. The U.S. Import demand for textiles can be found by transferring the U.S. net factor import vector to the origin and by expressing this vector as a combination of the two industry expansion vectors. This

In terms of algebra, the production side of the Heckscher-OhIIn-Vanek model takes the form $A Q_{\text {tex }}-V_{\max }$ where $A$ is the matrix in input vectors, $V_{\text {HIX }}$ is the Mexican factor supply vector and $Q_{\text {tax }}$ is the corresponding level of outputs. This express the factor supply $V_{\text {fax }}$ as a combination of the columns of $A$ with weights equal to the output levels $Q_{\max }$. Another way of saying this is that the total factor supply $v_{\text {max }}$ is allocated between the two Industries with each industry capital/labor ratio given. This produces the allocation of Mexican capital and labor to the Textile sector as 1llustrated in Figure 5 . The analogous equation for U.S. trade is $A T_{U S}=V_{U S}-s_{U S} V_{W}$ where $T_{U S}$ is the trade vector, $s_{u s}$ is the consumption share and $V_{W}$ is the world's factor supply. The excess factor supply vector $V_{u s}-s_{u s} V_{w}$ is depicted in Figure 5 linking the U.S. endowment point with the Iine representing the world's factor ratios. Trade balance is Implicitly being assumed since the U.S. factor 
allows us to find in the figure the supply of factors that could produce

U.S. textile imports. The same kind of vector addition allows us to find the allocation of Mexican factors to the production of textlles. In Figure 4 Mexican production of textiles is larger than U.S. textile Imports, and U.S. barriers would accordingly be completely circumvented by Mexican supply.

In figure 5 this construction is extended to identify the kinds of U.S. partners that would render completely ineffective any barriers that the U.S. might erect against non-members. The shaded region represents the factor endowments of all countries that have enough production of textiles to fully satisfy U.S. Import demand. It should be noted that this set includes countrles that, absent any trade barriers, would be importers, not exporters of textiles. In a free trade agreement with the United States, these countries would export enough of their own textile product to satisfy U.S. demand and would Import that amount and more from non-members to satisfy local consumption needs. Of course, local content restrictions would prevent simple transhipment of product through association members into to the United States, but these local content restrictions do not limit imports for local consumption. Accordingly the set of partners that would undo U.S. protectionism seems very large indeed.

This deterrence works in the other direction also. The possibility of U.S. exports to its partners deters their use of barriers, provided that the partner's trade is less than U.S. production supply point and the U.S. consumption point $s V_{\mathrm{H}}$ are on the same cost line: $w^{\prime}\left(V_{U S}-s_{U s} V_{w}\right)-0$ where $w$ is the vector of factor rewards. Just as in the case of outputs, the U.S. excess factor supply is decomposed into the sum of two vectors, one representing the factors needed to produce the textile imports and the other representing the factors need to produce the machinery imports. 
levels. For example, in Figure 5 the usual vector addition is used to find the level of U.S. production of machlnery and the corresponding partner net trade in factor services that is associated with this level of Imports. The partner's factor supply must be at least this close to the world factor supply line in order to assure a smaller partner level of machinery imports than U.S. production. SImIlarly, if the partner is an Importer of textiles, its factor supply vector must be not so far above the world factor supply line that its imports of textiles exceed the U.S. supply.

The shaded region in Figure 6 is found by intersecting the (Figure 4) set of partners that deter U.S. barrlers with the set of partners that are deterred by the U.S. from imposing barriers. This identifies a set of regional free trade agreements that have the property of "mutual assured deterrence", to borrow from another literature that has now lost fts relevance. This set of U.S. partners for mutual assured deterrence seems very large. A partner cannot be too small. A partner has to be more labor abundant than the UnIted States. If the partner is much smaller than the U.S., then it must be very labor abundant. If the partner is large compared with the U.S., then it must be moderately endowed in factors: not too labor abundant nor too capital abundant. v. REGIONAL ASSOCIATIONS: A MUTTI- CONE HECKSCHER-OHLIN MODEL

The one-cone Heckscher-Ohlin model leaves a very optimlstic view of the effect of free trade agreements on global efficiency. Other models may suggest different conclusions. In this section, we explore the two-factor four-good multi-cone Heckscher-Ohlin model depicted in Figure 7. Here it is assumed that there are three kinds of countries: (1) Low-wage countries produce a labor-Intensive mix of products, 
apparel and textiles. (2) Moderate wage countries produce an Intermediate $m i x$ of products: textiles and machinery. (3) High-wage countries produce a capital intensive mix of products: machinery and chemicals. In the figure are drawn arrows representing the factor endowments of Mexico and the United States. Mexico is placed in the low-wage cone and the United States is placed In the hIgh-wage cone. What happens when Mexico and the United States are combined Into a regional trade association that Imposes trade barriers against the products imported from non-members? Under what conditions do these barriers have absolutely no effect? Does the regional association make it more or less likely that Its nembers will impose barriers against non-members? The answers to these questions implled by the multi-cone Heckscher-Ohlin model depend on whether the regional association Increases the mobility of factors among its members. Regional associations with and without factor moblitty.

\section{A. Associations with Internal Factor Mob1lity}

In Figure 7. Mexico and the United States are located in different cones of diversification with different wage rates and different compensation rates for capital. If the free trade agreement eliminates the barriers to capital or to labor flows between these two countries then Mexico and the United States form a new economic unit that lies in one cone or the other. This regional association cannot be a holographic image of the world's economy and trade with non-members will occur and may even be more than before the agreenent. Barrlers that are erected against third country imports thus st1ll have an effect after the agreement is fully in place. But there are circumstances in which these barriers might not be erected because they divert but do not 
protect or because they cause politically unacceptable reglonal income redistribution.

In Figure 7 the arrow representing the U.S. and Mexico combined is placed in the intermediate cone which is sulted to the production of textiles and machinery. This integrated equilibrium is created by a combination of capital movements Into Mexico from the United States and/or labor migration Into the United States from Mexico. Enough factor flows have to occur to drag both the U.S. endowment point and the Mexican endowment point into the Intermediate cone. This factor mobility thus Implies lower wages in the United States and the loss of Its capital-intensive chemicals sector, possibly replaced by textlles if the flow of Mexican migrant labor is great enough. Mexico ends up with higher wages but loses the apparel sector. Mexico may produce textlles if the capital flow from the United States is great enough. The figure fllustrates the more probable case of a capital flow out of the U.S. that terminates when the U.S. endowment point fust gets into the central cone.

In the integrated equilibrium that is depicted in this figure, both the United States and Mexico gain from the factor moblifty. The original US endowment point is located on the cc unit cost line, indicating that the inftial US GDP (and GNP) is one unit. In the integrated equilibrium, factor earnings equal one when the factor combination lies on the bb unit cost line. You can see that in the figure the dark arrow depicting the US total factor supply extends beyond this bb line, the amount that it does so Indicating the gain in US factor earnings (GNP) as a result of the free trade agreement. If the integrated equilibrium is accomplished by a capital flow out of the 
U.S., the GDP cannot rise however. The figure depicts this with U.S. resident factor supplies earning less than one unit after integration. of course this reduction in resident earnings is more than offset by the earnings of capital located in Mexico. Perhaps it bears repeating for emphasis: The gains to the U.S. from the agreement are greater, the farther is the U.S. endowment point from the integrated cone of diversification (the machinery expansion ratio). But this additional gain in GNP comes necessarlly with a smaller GDP, with more and more U.S. earnings coming in the form of repatriated capital earnings. Mexico also gains overall from the association. The original Mexican endowment point is not enough to produce a unit value of GDP since it falls short of the a curve defining the original Mexican unit cost Iine. But in the integrated equilibrium, the Mexican total earnings (GNP) jumps up to one unit, since the Mexican endowment point is located on the bb curve. Mexican GDP is even higher, but all those additional earnings are owed to owners of U.S. capital.

The message here seems pretty accurate: Although both countries will gain overall, U.S. labor and Mexican capital stand to lose from a free trade agreement. Until the product mix is similar in Mexico and the United States, we should be expecting capital flows south and labor flows north.

\section{Free Trade Agreement}

Now consider the impact of trade barrlers after achfevement of the integrated equilibrium depicted in Figure 7 . In the integrated freetrade equilibriun both the United States and Mexico have to import chemicals and apparel from third sources. Either machinery or textiles might be imported as well. The impact of barriers on machinery and 
textiles is similar to the two-product model discussed in the previous section. The difference is that in this four-good model the import levels of machinery and textiles are likely to be less since both chemicals and apparel are necessarily imported and must be paid for with exports of either machinery or textiles or both. Because the import levels are less, the region of mutual assured deterrence depicted in Figure 6 gets even greater, at least as it relates to protection of machinery and textiles.

What about barriers against the other imports: Apparel and Chemicals? With low barriers there is no internal production at all and these low barriers can only raise the prices that U.S. and Mexican consumers have to pay. Suppose instead that the United States were to impose barriers on imports of apparel that are great enough to justify production and great enough possibly to raise wages. In the figure, this means that the apparel isoquant is shifted inward to the point that it touches the unit-isocost 1ine. If it shifts in further, then the Stolper-Samuelson effect would kick in and wages would go up in both the United States and Mexico. With the higher wages, textile producers would be forced out of business and production would concentrate on machinery and apparel. There is a force, however, that works against this outcome. All the apparel production of the association has to be sold in the U.S. protected marketplace. If the U.S. demand at the high price is not as high as the total association production, then it is impossible to raise the price of apparel high enough to raise U.S. wages unless protection were also granted to the textile sector. 
The bottom Iine here is that a free trade agreement implies globalism, more strongly in the multi-product model with internal factor flows than in the two-product one-cone model.

2. Customs Union

Next consider the case of a customs union with a common set of external barriers. A tariff wall imposed on textile imports by both Mexico and the United States must of course raise the price of textiles in both countries and set in motion the identical Stolper-Samuelson response in both locations. But the mixed regional incentives to impose trade barriers may lower their chances of making it through the legislative process. The reason there are mixed regional incentives is that Mexico, even after factor migration, is relatively well endowed in labor and has a relatively great incentive to seek measures that raise the price of the labor intensive product.

\section{B. Associations without Internal Mobility}

Next consider the case without factor flows between Mexico and the United States. Suppose as in Figure 7 that Mexico and the United States are located in different cones of diversification. In the absence of protection, neither textiles nor apparel are produced in the United States and neither chemicals nor machinery are produced in Mexico. Unlike the case with factor mobility, it is possible that Mexico and the United States do not need to trade with third parties to reap completely the gains from international exchange. One possibility is that Mexico and the United States form an exact replica of the world economy. Even If they do not, they may be able together to satisfy perfectly the combined demand for all products at world prices. 
If the association does have external trade, then trade barriers can have an effect. Barriers to imports of textiles and apparel may raise the U.S. price high enough to support U.S. production of these products. If both textiles and apparel are protected, the U.S. factor prices apply to Mexican production. This represents a big gift to Mexico from U.S, consumers. The size of this gift is measured in Figure 7 by the difference between the Mexican factor supply vector along the bb cost line and along the cc cost line.

These high prices are sustainable only if Mexico is so small that the marginal suppliers of textiles and apparel are third countries subject to the trade barriers. If the association is a free trade agreement, Mexico will export all product to the high-priced U.S. marketplace and import for consumption purposes from cheap third suppliers. All this output and more has to be absorbed by U.S. consumers to sustain the prices in the U.S. If the association is a customs union, then part of Mexican output is absorbed for Mexican consumption purposes and less is available for the U.S. marketplace.

The cases in which only one of the products is protected are left as an exercise.

VI. EVIDENCE

A small amount of evidence is provided in this final section concerning the possibility of Mutual Assured Deterrence in the proposed North American Free Trade Agreement. Figure 6 suggests that MAD occurs when a smaller partner of the United States is not too small nor too similar to the U.S. Figure 8 is intended informally to indicate if this seems in fact to hold between the United States, Mexico and Canada. This figure indicates the percentages of world totals of various factor 
supplies for various countries and regions. GDP figures are included as an (imperfect) proxy for physical capital.

The United States is Indicated by the darkest bars at the top of the figure. The relatively long dark bars identify factors of production in which the United States is abundantly supplied. Energy leads the list with consumption slightly larger than production. After that is the proxy for physical capital: GDP. Another abundant factor is managers though the distinction between technical, managerial and skilled workers may have more to do with Job descriptions than with skill differences. The relatively short dark bars identify factors of production in which the United States is poorly supplied. According to these data the U.S. is scarce in population, and in unskilled workers.

A partner for the United States that would be supportive of globalism would tend to make up these labor scarcities without exacerbating the energy and physical capital abundance. Mexico is helpful in that regard, but is not large enough to increase the share of population or the share of unskilled workers to the combined level of the GDP share or the shares of several of the other abundant resources. Canada seems too similar to the United States to offer much deterrent to the U.S. barriers against labor-intensive products.

Although this figure makes Mexico seem small, the discussion surrounding Figure 5 indicates that a partner that deters U.S. barriers can be much smaller than the U.S. If Its factor supply is very different. The most direct way of determining if Mexico is large enough to deter U.S. protectionism is to compare Mexican output levels with U.S. Import levels as is done in Table 1 using 1984 data. The first column contains the 1984 Mexican share of U.S. imports. In none of 
these sectors does this current trade share exceed 10 per cent. The next column, however, contalns the relevant ratio: Mexican output divided by U.S. imports. Here there are quite few sectors wh1ch oven In 1984 there is enough Mexican production to satisfy U.S. Import demand.

The Mexican liberalization that began in 1985 should eventually generate a substantial Increase in productivity and greatly increase the levels of Mexican output. To get a very rough sense of the potential effects of productivity Increases, data on Itallan productivity are used to compute hypothetical output levels for a liberalized Mexico. These are reported in the last column of Table 1 . W1th this adjustment there are many more sectors for which Mexican output would exceed U.S. Imports and therefore deter U.S. protectionism. Two glaring exceptlons are appare1 and footwear.

This quick look at some data doesn't allow any strong conclusions, but that won't hold me back. The North American Free Trade Agreement is very compatible with global free trade. Indeed if it is not ratifled, we can expect very substantial 1ncreases in barrlers erected by the . United States especially against Aslan products. If it is ratifled, the protective effect of U.S. barriers against Asian products would be greatly reduced, and these barrlers would be less likely to be erected. 


\section{REFERENCES}

Corden, W. Max (1984), "The Normative Theory of International Trade," in Ronald W. Jones and Peter B. Kenen, Handbook of International Economics, Volume I, Amsterdam: North Holland, 63-130.

Gardner, Grant W. and Kimbrough, Kent P., The Economics of CountrySpecific Tariffs," International Economic Review , August 1990. $31,575-588$.

Goto, Junichi and Hamada, Kolchi, "Economic Preconditions for the Astan Regional Integration," Research Institute for Economics and Business Administration, Kobe University, No.31, 1993.

Krugman, Paul (1980) "Scale Economies, Product Differentiation, and the Pattern of Trade," American Economlc Revlew 70, $950-959$.

Krugman, Paul (1991a), "Is Bilateralism Bad?" In E. Helpman and A. Razin, eds. International Trade and Trade Policy, Cambridge, MIT Press, 9-23.

Krugman, Paul (1991b) "The Move to Free Trade Zones," in Polfcy Implications of Trade and Currency Zones, a Symposium Sponsored by the Federal Reserve Bank of Kansas City, Jackson Hole, Wyoming, August, pp. 7-42.

Lal, Depak, "Trade Blocs and Multilateral Free Trade," unpublished manuscript, 1993.

Lipsey, R.G. (1957) "The Theory of Customs Unions: Trade Diversion and Welfare," Economica, N.S., 24, No. 93, 40-46.

McCulloch, Rachel and Pinera, Jose, Trade as Aid: The Political Economy of Tariff Preferences for Developing Countries," American Economic Review , December 1977, 67, 959-967. 
25

de Melo, Jaime, Rodrick, Dan and Panagarlya, Arvind, "The New

Regionalism: A Country Perspective," CEPR Discussion Paper No.

175. September, 1992.

Shot, Jeffrey, ed. , Free Trade Areas and US Trade Policy, Washington,

D.C.: Institute for International Economics, 1989.

Vanek, J. (1965). General Equilibrium of International Discrimination:

The Case of Customs UnIons, Cambridge: Harvard University Press.

Winters, L. Alan, "The European Community: A Case of Successful

Integration?," Center for Economic Policy Research, Discussion

Paper No. 755, January, 1993. 
Figure' 1

\section{Stolper Samuelson with Mixed Ownership} Factors Needed to Purchase Commodities

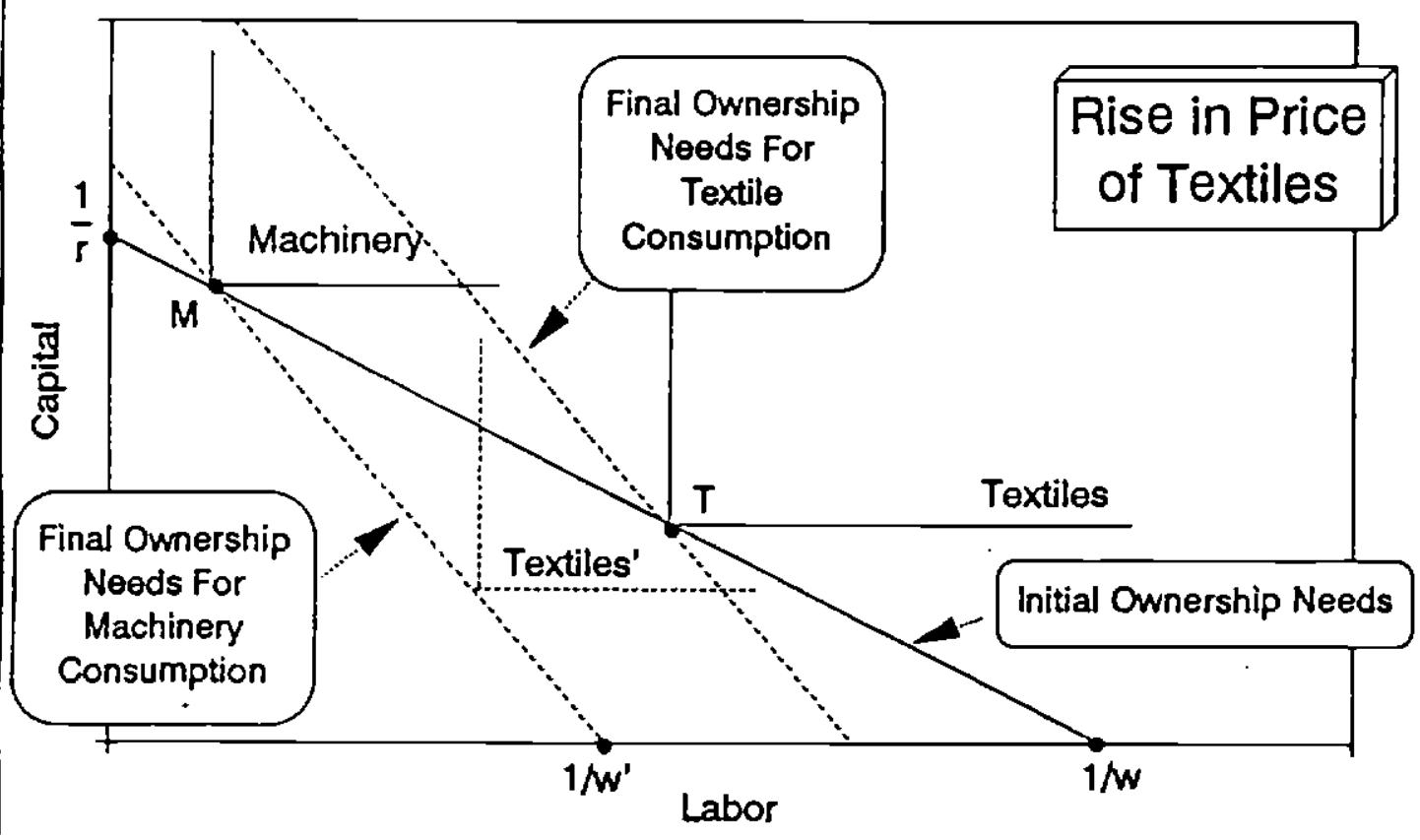


Figure 2

\section{Trade Diversion and an FTA: Tariff}

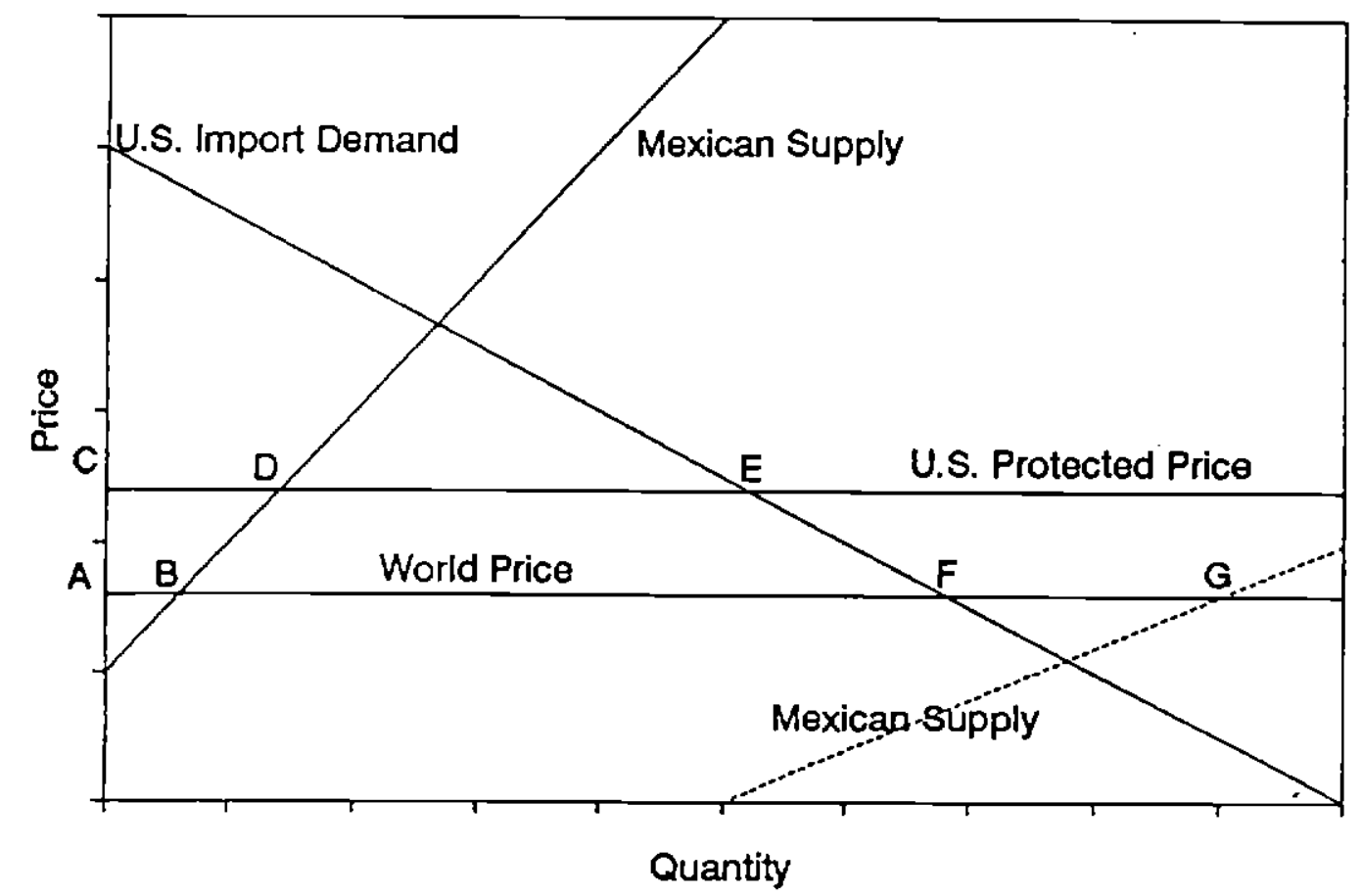

t:ilareldemand 


\section{Trade Diversion and an FTA: Quota}

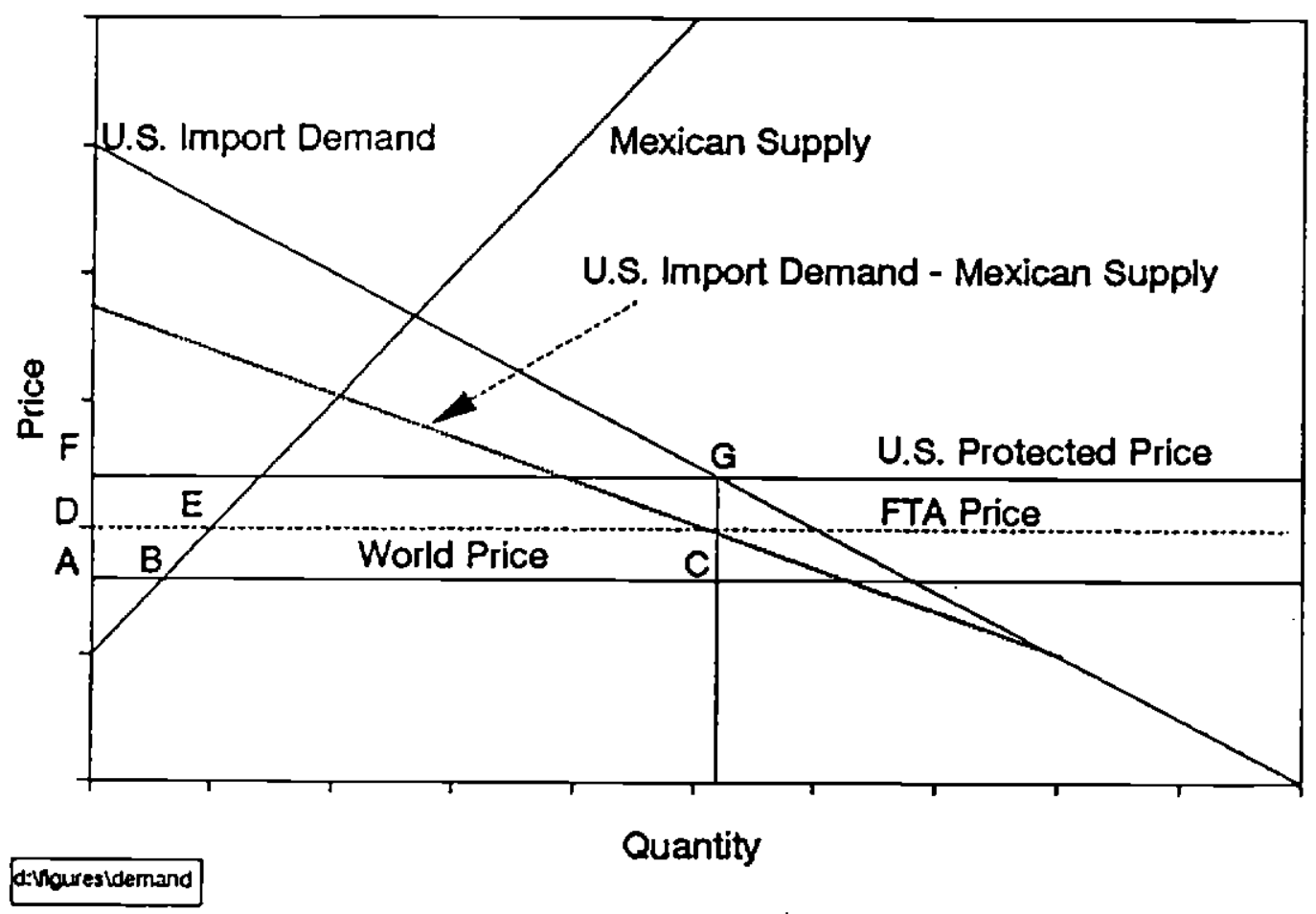




\section{Mexican Exports Deter U.S. Protection}

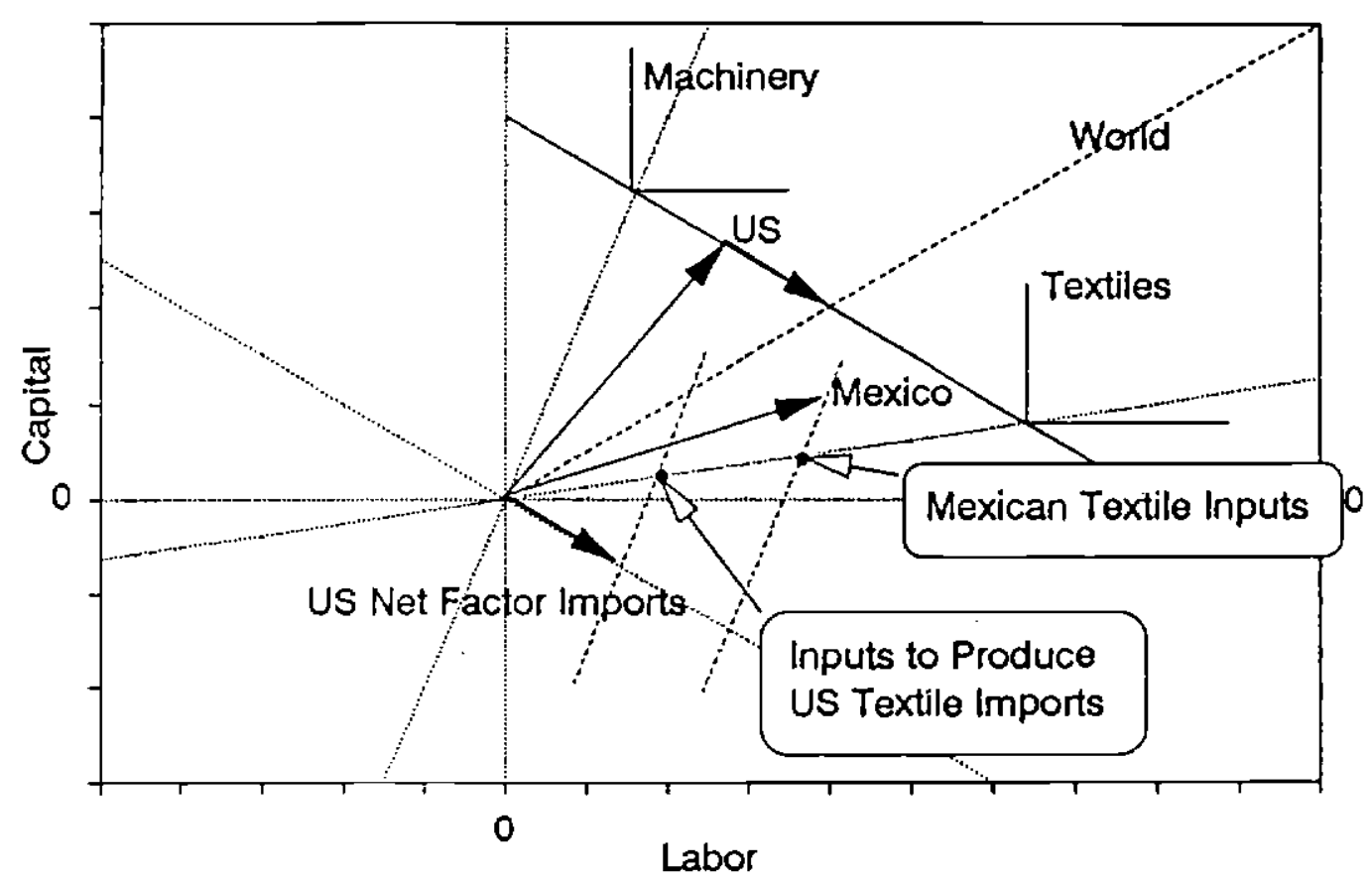


Figure 5

\section{Partners That Deter U.S. Protection}

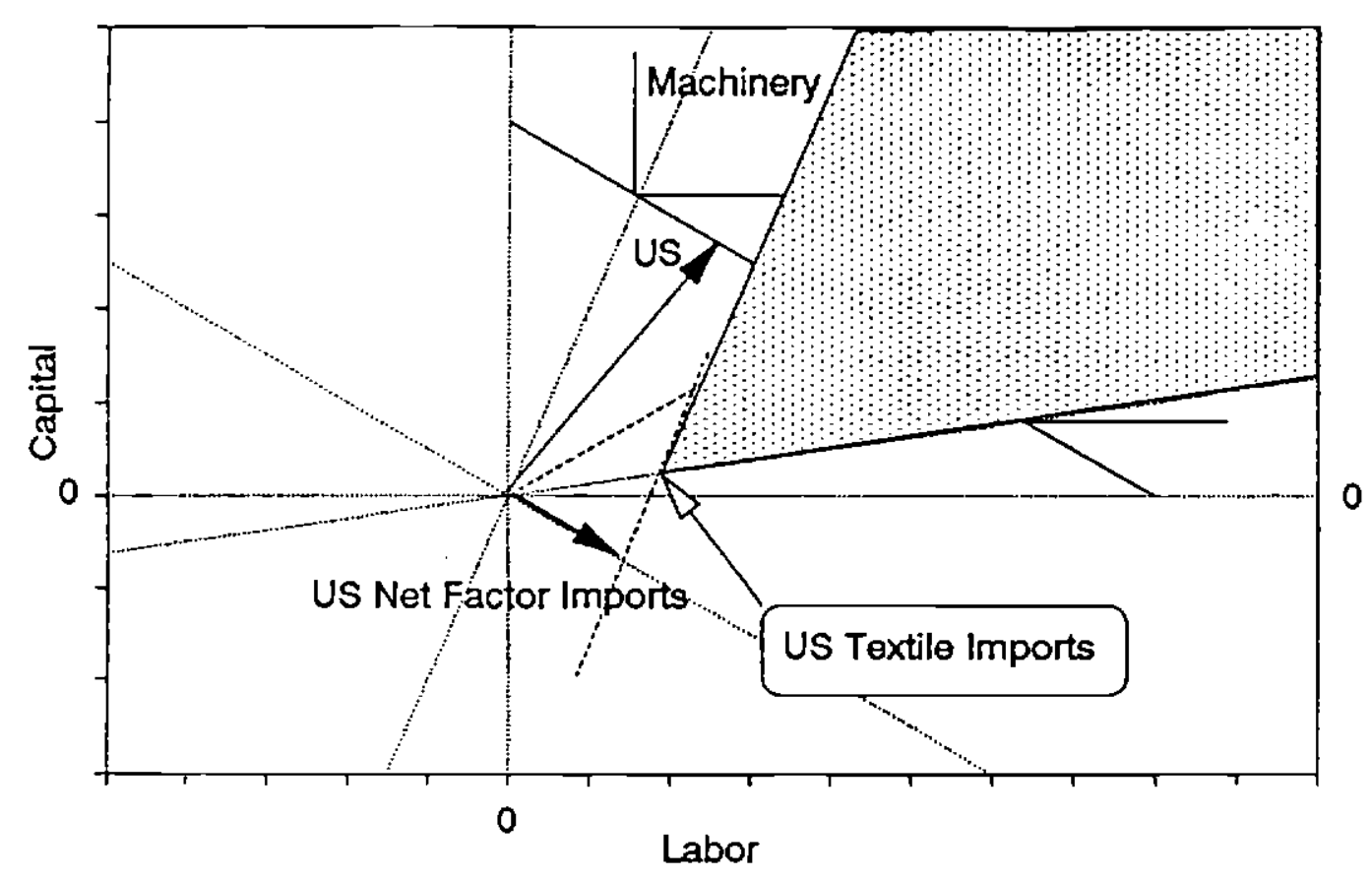




\section{Mutual Assured Deterrence}

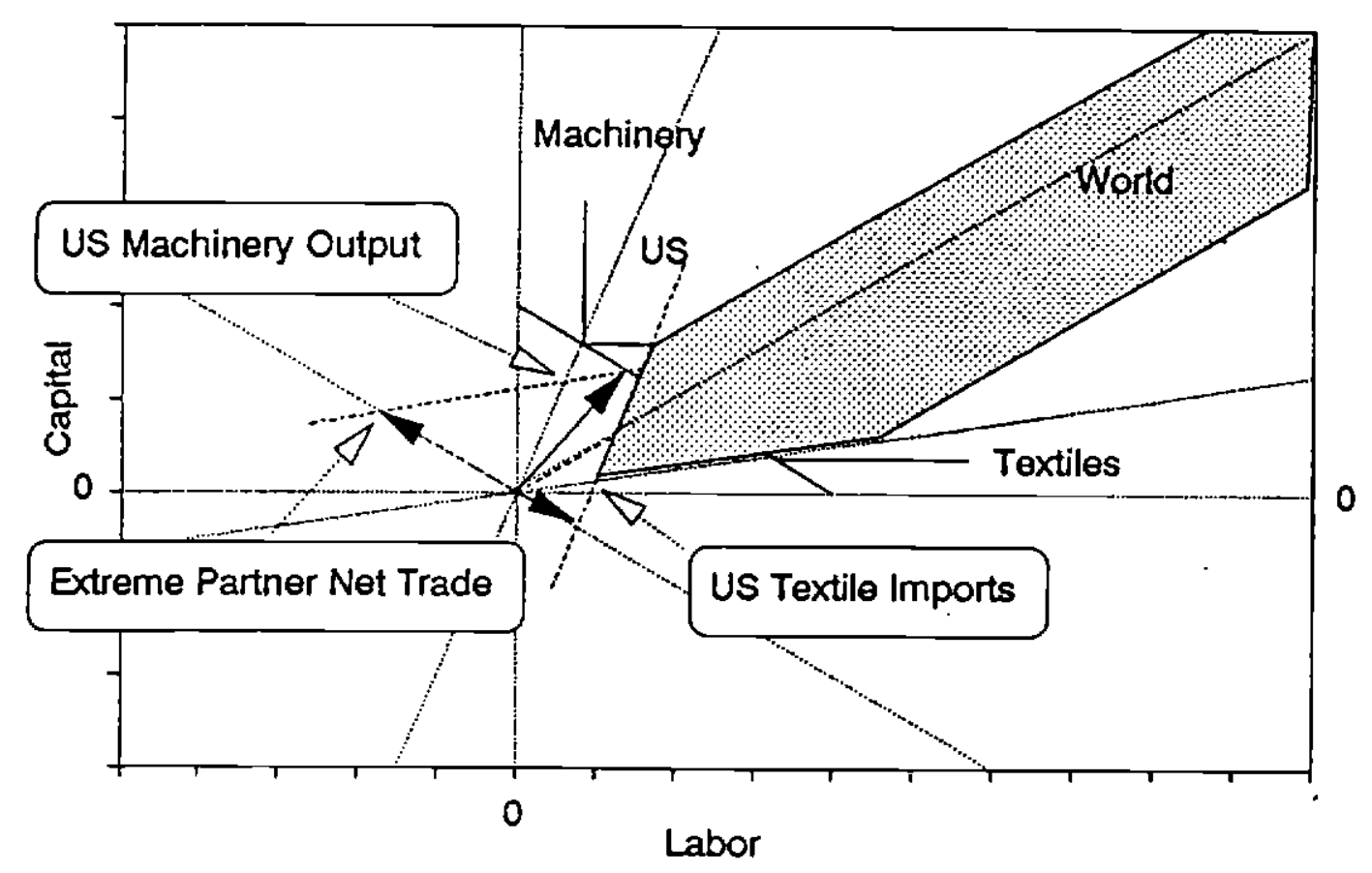


rigure,

\section{Regional Association with Factor Flows Cones of Diversification}

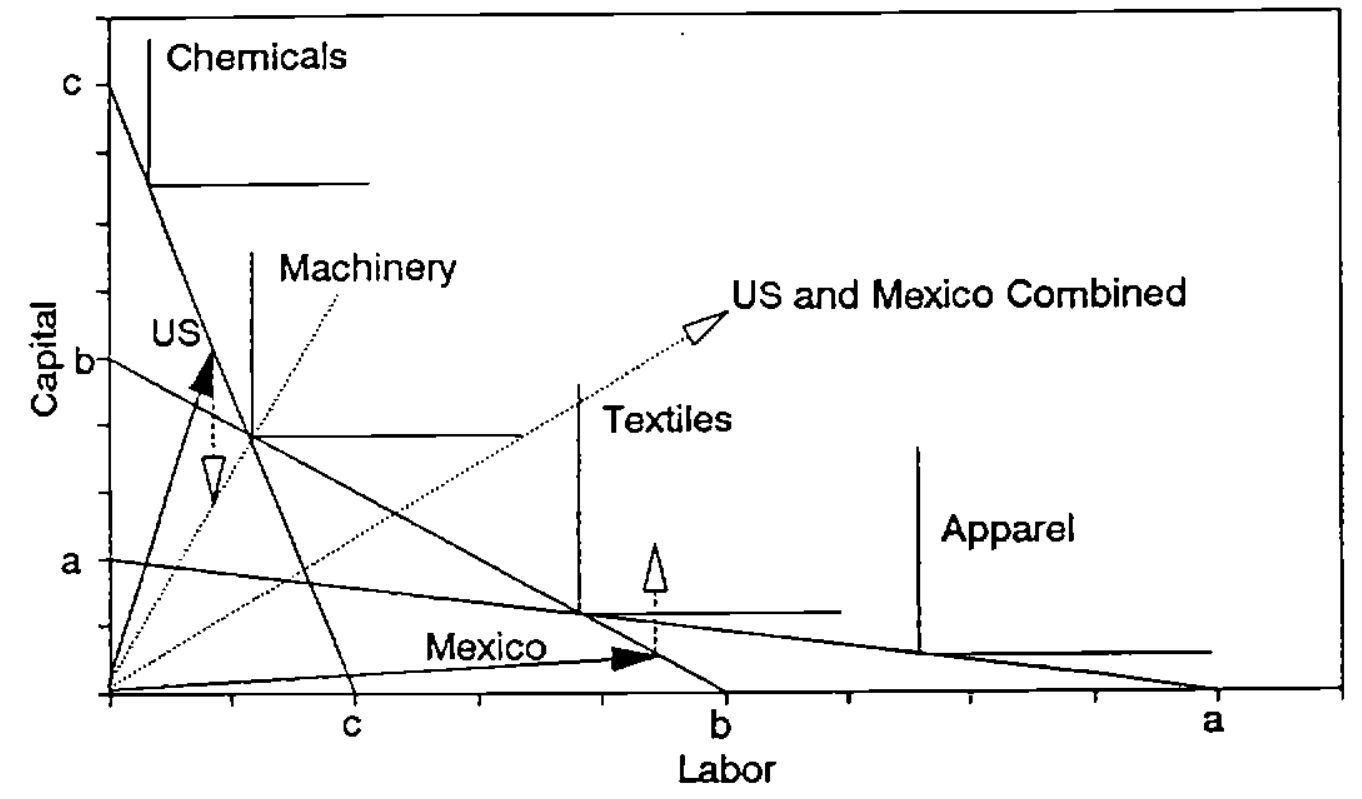




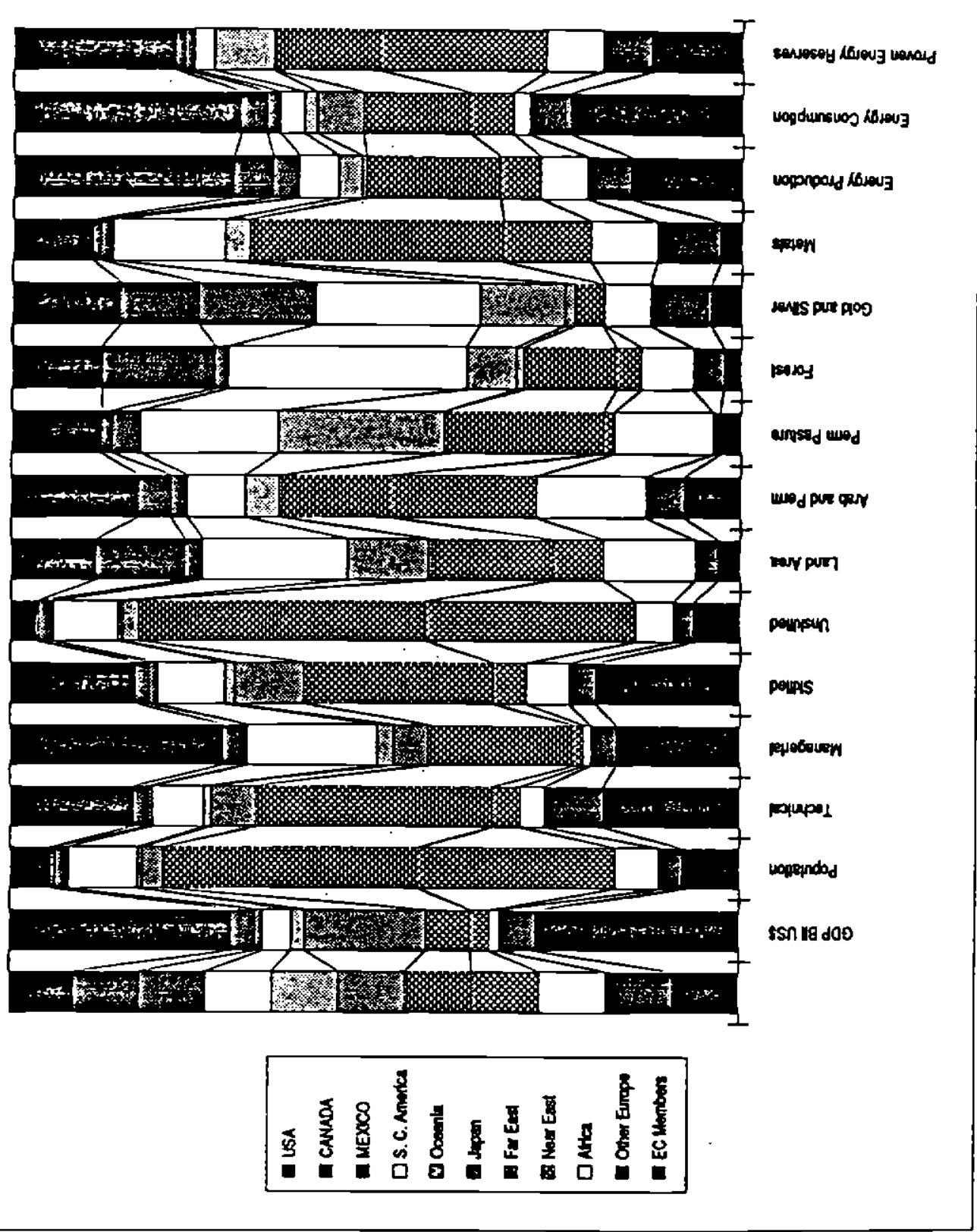


Table I

Mexican 1984 Trade and Output:

Actual and Hypothetical with Italian Productivity

\begin{tabular}{|c|c|c|c|c|}
\hline ISIC & & $\begin{array}{l}\text { Mexican } \\
\text { Share of } \\
\text { U.S. } \\
\text { Imports } \\
\end{array}$ & \multicolumn{2}{|c|}{$\begin{array}{l}\text { Mexican OutpuV } \\
\text { U.S. Imports }\end{array}$} \\
\hline 3411 & Pulp,Paper & 0.03 & 11.44 & 23.89 \\
\hline 314 & Tobacco & 0.06 & 8.37 & 13.06 \\
\hline 342 & Printing,Publishing & 0.01 & 1.56 & 4.13 \\
\hline 311 & Food & 0.04 & 1.45 & 1.96 \\
\hline 369 & Other Non-Metallic Manufactures & 0.09 & 1.37 & 4.12 \\
\hline 352 & Other Chemicals & 0.01 & 1.27 & 245 \\
\hline 313 & Beverages & 0.03 & 1.24 & 0.90 \\
\hline 321 & Textiles & 0.02 & 1.07 & 3.22 \\
\hline 3513 & Synthetic Resins & 0.04 & 1.06 & 3.39 \\
\hline 354 & Petroleum Products & 0.03 & 0.89 & 0.91 \\
\hline 3522 & Drugs,Medicines & 0.01 & 0.78 & 0.23 \\
\hline 362 & Glass and Ceramics & 0.08 & 0.60 & 1.63 \\
\hline 371 & Iron,Sieel & 0.02 & 0.59 & 209 \\
\hline 356 & Plastic Products & 0.02 & 0.53 & 1.90 \\
\hline 355 & Rubber Products & 0.01 & 0.52 & 1.18 \\
\hline 351 & Industrial Chemicals & 0.04 & 0.49 & 1.43 \\
\hline 323 & Leather, Leather Products & 0.01 & 0.45 & 1.77 \\
\hline 3511 & Basic Chemicals & 0.05 & 0.40 & 1.15 \\
\hline 361 & Pottery,China & 0.02 & 0.38 & 3.06 \\
\hline 331 & Wood Products & 0.02 & 0.31 & 6.80 \\
\hline 341 & Paper & 0.02 & 0.30 & 0.71 \\
\hline 381 & Metal Products & 0.03 & 0.29 & 0.90 \\
\hline 353 & Petroleum Refineries & 0.05 & 0.29 & 1.19 \\
\hline 332 & Furniture & 0.05 & 0.28 & 1.15 \\
\hline 324 & Footwear & 0.02 & 0.25 & 0.79 \\
\hline 322 & Wearing Apparel & 0.02 & 0.14 & 0.44 \\
\hline 372 & Non-Ferrous Me1al Products & 0.05 & 0.12 & 0.00 \\
\hline 3841 & Shipbuilding & 0.03 & 0.12 & 3.03 \\
\hline 3843 & Motor Vehicles & 0.02 & 0.11 & 0.43 \\
\hline 384 & Transport Equipment & 0.02 & 0.10 & 0.48 \\
\hline 390 & Other Industrial Products & 0.01 & 0.09 & 0.25 \\
\hline 382 & Machinery & 0.02 & 0.08 & 0.74 \\
\hline 383 & Electrical Machinery & 0.08 & 0.08 & 0.55 \\
\hline 385 & Professional Instruments & 0.03 & 0.07 & 0.23 \\
\hline 3832 & Radio,TV & 0.06 & 0.05 & 0.29 \\
\hline 3825 & Office,Computing Equipmen। & 0.02 & 0.02 & 0.06 \\
\hline
\end{tabular}




\begin{tabular}{|c|c|c|c|c|c|}
\hline \multicolumn{6}{|c|}{ Notes: World Factor Supplies } \\
\hline \multicolumn{6}{|c|}{ Regional Breakdown by Country } \\
\hline \multicolumn{6}{|c|}{\begin{tabular}{|l|l|l|} 
NAFTA & & \\
\end{tabular}} \\
\hline USA & CANADA & $M E \times C O$ & & & \\
\hline \multirow{2}{*}{\multicolumn{6}{|c|}{ S. C. America }} \\
\hline $\begin{array}{l}\text { P. C. America } \\
\text { BOUVIA }\end{array}$ & & & & & \\
\hline BRAZL & & $\begin{array}{l}\text { VENEZUALA } \\
\text { BAHAMAS }\end{array}$ & & ANTIUES & \\
\hline CHUE & & BARBADOS & & COSTA RICA & \\
\hline COLOMBIA & & BEPMUDA & & \\
\hline PARAGUAY & & \multicolumn{2}{|c|}{ BR. VIRGIN ISLANDS } & \multicolumn{2}{|l|}{ EL SALVADOR } \\
\hline PERU & & HATI & & NICARAGUA & \\
\hline SUPINAME & & HONDURAS & & PANAMA & \\
\hline URUGUAY & & JAMAICA & & PUERTORLO & \\
\hline & & & & & \\
\hline \multicolumn{6}{|l|}{ Oceania } \\
\hline AUSTRALA & & FLI & & \multirow{2}{*}{\multicolumn{2}{|c|}{$\begin{array}{l}\text { NEW CALEDONIA } \\
\text { PAPUA NEW GUINEA }\end{array}$}} \\
\hline NEW ZEALAND & & \multicolumn{2}{|c|}{ FRENCH POLYNESLA } & & \\
\hline \multicolumn{6}{|c|}{ AMERICAN SAMOA } \\
\hline & & & & & \\
\hline \multicolumn{6}{|l|}{ Japan } \\
\hline & & & & & \\
\hline \multicolumn{6}{|l|}{ Far East } \\
\hline ERUNA & & PHIUPPINES & & TAIWAN & \\
\hline HONG_KONG & & SNGAPORE & & THAILAND & \\
\hline WOONESIA & & \multicolumn{2}{|c|}{ KOREA SOUTH } & CHINA & \\
\hline \multicolumn{6}{|l|}{ MALAYSIA } \\
\hline & & & & & \\
\hline \multicolumn{6}{|l|}{ Near East } \\
\hline BANGLADESH & & PAKISTAN & & EGYPT & \\
\hline INOLA & & SRI LANKA & & ISRAFI & \\
\hline NEPAL & & EAHRAIN & & SYRIA & \\
\hline \multicolumn{6}{|l|}{ Africa } \\
\hline ALGERIA & & GAMBIA & & \multicolumn{2}{|l|}{ SOUTHAFRICA } \\
\hline BENNN & & GHANA & & SWAZJLAND & \\
\hline BOTSWANA & & MALAWI & & TOGO & \\
\hline BURUNDI & & MAURIUS & & TUNISIA & \\
\hline CA.R. & & NGP & & ZAMBLA & \\
\hline CAMEROON & & NIGERIA & & ZMMBABWE & \\
\hline \multicolumn{2}{|c|}{ EOUATORIAL GUINEA } & SEYChEULES & & & \\
\hline & & & & & \\
\hline \multicolumn{6}{|l|}{ EC Members } \\
\hline BELGUM & & GPEOE & & \multicolumn{2}{|l|}{ NETHERLANDS } \\
\hline DENMARK & & IRELAND & & PORTUGAL & \\
\hline
\end{tabular}




\begin{tabular}{|c|c|c|c|c|}
\hline \multirow{3}{*}{\begin{tabular}{l|} 
FPANCE \\
GERMANY EAST \\
GEPMANY WEST
\end{tabular}} & & \begin{tabular}{|l|l|l|} 
ITALY & \\
\end{tabular} & SPAN & \\
\hline & & \multirow{2}{*}{\multicolumn{2}{|c|}{ LXPMBOURG }} & \\
\hline & & & & \\
\hline \multirow{2}{*}{\multicolumn{5}{|c|}{ Other Europe }} \\
\hline & & & & \\
\hline AUSTRLA & & SWIZERLAND & CYPPUS & \\
\hline FINLAND & & \begin{tabular}{|l|l} 
BULGAPIA & \\
\end{tabular} & GIBRALTAR & \\
\hline NOAWAY & & POLAND & TURAFY & \\
\hline \multicolumn{5}{|l|}{ SWEDEN } \\
\hline Categories & & \multicolumn{2}{|c|}{ All data 1990 unless otherwise noted } & \\
\hline \multicolumn{5}{|l|}{ GDP BII US\$ } \\
\hline \multirow[t]{3}{*}{ Sources } & \multicolumn{3}{|c|}{ European Marketing Data and Statistics } & \\
\hline & \multicolumn{3}{|c|}{ Inlemalional Marketing Data and Statistics } & \\
\hline & & & & \\
\hline \multicolumn{5}{|l|}{ Population } \\
\hline \multirow[t]{2}{*}{ Source } & \multicolumn{3}{|c|}{\begin{tabular}{|l|l|} 
UN Monthly Bullelin of Stalistics & \\
\end{tabular}} & \\
\hline & \multicolumn{3}{|c|}{ Data are mid-year international estimates } & \\
\hline Unit & \multicolumn{2}{|c|}{ Millions of People } & & \\
\hline & & & & \\
\hline Technlcal & \multicolumn{2}{|l|}{ Managerlal } & & \\
\hline Skllled & Unskilied & & & \\
\hline \multirow[t]{2}{*}{ Sources } & \multicolumn{3}{|c|}{ European Marketing Data and Statistics } & \\
\hline & \multicolumn{3}{|c|}{ Intemalional Marketing Data and Statistics } & \\
\hline Units & \multirow{2}{*}{\multicolumn{2}{|c|}{000 's of workers }} & & \\
\hline & & & & \\
\hline Technical & \multicolumn{3}{|c|}{ Includes protessional, technical, and related workers } & \\
\hline Managerial & \multicolumn{3}{|c|}{ Includes administrative and managerial workers } & \\
\hline Skilled & \multicolumn{3}{|c|}{ Includes clerical, sales, service and related workers } & $\cdot$ \\
\hline \multirow[t]{3}{*}{ Unskilled } & \multicolumn{4}{|c|}{ Compiled by subtracting the above total from total country } \\
\hline & populatio & on between the & and 64 & \\
\hline & & & & . \\
\hline Land Area & Arab and $\mathrm{F}$ & Perm & & \\
\hline Forest & Perm Past & ture & & \\
\hline Source & FAO Annua & al Production 1 & & \\
\hline & Food and $A$ & Agriculture Org & the United Nat & lons \\
\hline Units & 000's HA & & & \\
\hline & & & & \\
\hline Land Area & Total Land & Area & & \\
\hline Arab and Perm & Arable land & and permane & & \\
\hline Forest & Forest and & Woodlands & & \\
\hline Perm Pasture & Permanent & Pasture & & \\
\hline Gold and Silvet & & & & \\
\hline Metals & & & & \\
\hline Sources & European $A$ & Marketing Data & & \\
\hline
\end{tabular}


Notes

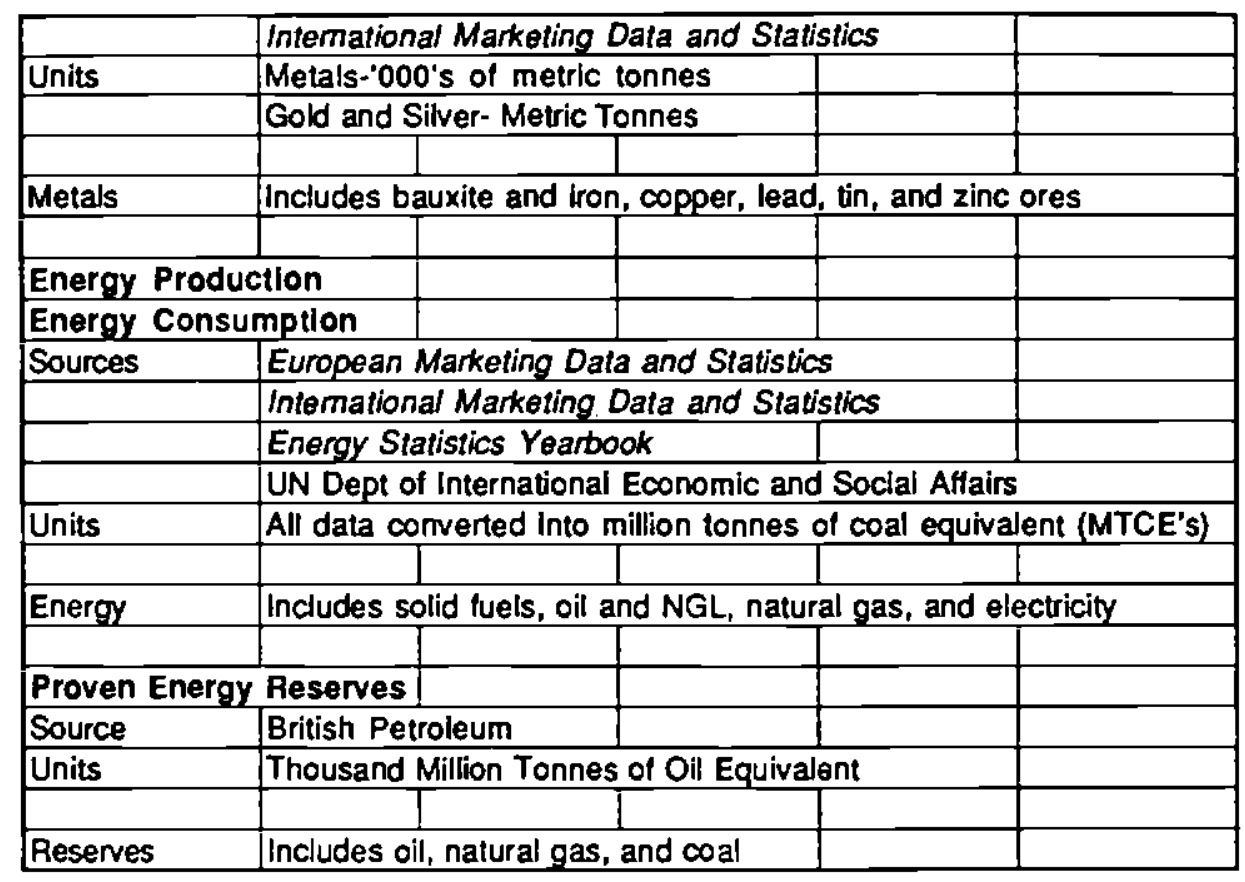


To order any of these papers, see instructions at the end of the list. To subscribe to all NBER Working Papers or the papers in a single area, see instructions inside the back cover. A complete index of all NBER Working Papers may be accessed using our gopher server at nberdharvardedu.

Number

4697

4698

4699

4700 .

4701

4702

4703

4704

4705

4706

4707

4708

4709

4710

4711
Author(s)

Sebastian Edwards

John H. Cochrane

Lawrence J. Christiano

Martin Eichenbaum

Charles Evans

Paul Gerllex

Roland Sturm

Bruce Davidson

Edward J. Kane

Min-Teh Yu

Shmuel Kandel

Robert F. Stambaugh

Jason G. Cummins

R. Glenn Hubbard

R. Glenn Hubbard

Darius Palia

Daniel R. Feenberg

Harvey S. Rosen

Bennet T. McCallum

Claudia Goldin

Henry Saffer

Alan J. Auerbach

Robent E. Lipsey

Alan M. Taylor Jeffrey $\mathbf{G}$. Williamson
Title

Date

Macroeconomic Stabilization in Latin America: Recent Experience and Some Sequencing Issues

Shocks

$4 / 94$

The Effects of Monetary Policy Shocks:

Some Evidence from the Flow of Funds

$4 / 94$

Information and the Demand for

Supplemental Medicare Insurance

$4 / 94$

How Much Did Capital Forbearance Add to the Tab for the FSLIC Mess?

Portfolio Inefficiency and the

$4 / 94$

Cross-Section of Expected Returns

$4 / 94$

The Tax Sensitivity of Foreign Direct

Investment: Evidence from Firm-Level

Panel Daca

Executive Pay and Performance: Evidence

$4 / 94$

From the US. Banking Industry

Recent Developments in the Marriage Tax

$4 / 94$

A Semi-Chassical Model of Price Level

$4 / 94$

Adjustment

The UShaped Female Labor Force

$4 / 94$

Function in Economic Development and

Economic History

Alcohol Advertising and Motor Vehicle Fatalities

$4 / 94$

The U.S. Fiscal Problem: Where We Are, How

$4 / 94$

We Got Here, and Where We're Going

U.S. Foreign Trade and the Balance of

$4 / 94$

Payments, 1800-1913

Convergence in the Age of Mass Migration

$4 / 94$ 
To order any of these papers, see instructions at the end of the list. To subecribe to all NBER Working Papers or the papers in a single area, see Instructions inside the back cover. A complete index of all NBER Working Papers may be accessed using our gopher server at nber harvardeda.

Number

4712

4714

4715

4716

4717

4718

4719

4720

4721

4722

4723

4724

4725

4726

4727
Author(s)

Rosanne Altshuler

Jack Mintz

Gordon H. Hanson

Alberto F. Ades

Edward L. Glaeser

Alberto F. Ades

Edward L. Glaeser

Edward E. Leamer

Joel M. Dickson

John B. Shoven

James M. Hutchinson

Andrew W. Lo

Tomaso Poggio

Andrew Alkeson

Christopher Phelan

Andrew W. Lo

Jiang Wang

Steven D. Levilt

James M. Poterta

Lakshmi Shyam-Sunder

Stewart C. Myers

Nancy L. Rose

Andrea Shepard

Steven N. Kaplan

Richard S. Ruback

Jong-Wha Lee

John Baldwin

Timothy Dunne

John Halkiwanger

Peler C. Reiss

Ingrid $M$. Wemer
Title

Date

U.S. Interest Allocation Rules:

Effects and Policy

Regional Adjustment to Trade Liberalization

$4 / 94$

Evidence on Growth, Increasing Returns and

$4 / 94$

the Extent of the Market

Trade and Circuses: Explaining Urban Giants

$4 / 94$

Trade, Wages and Revolving Door Ideas

$4 / 94$

A Stock Index Mutual Fund Without

Net Capital Gains Realizations

$4 / 94$

A Nonparametric Approach to Pricing and

$4 / 94$

Hedging Derivative Securities Vis

Leaming Networks

Reconsidering the Costs of Business

$4 / 94$

Cycles with Incomplete Markets

Implementing Option Pricing Models

When Asset Returns Are Predictable

Congressional Distributive Politics

and State Economic Performance

Testing Static Trade-Off Against Pecking

Onder Models of Capital Structure

Firm Diversification and CEO Compensation: Managerial Ability or Executive Entrenchment?

The Valuation of Cash Flow Forecasts:

An Empirical Analysis

Capital Goods Imports and Long-Run Growth

$4 / 94$

A Comparison of Job Creation and Job

$5 / 94$

Destruction in Canada and the United States

Transaction Costs in Dealer Markels:

$5 / 94$ 
To order any of these papers, see lnstructions at the end of the tist. To subscribe to all NBER Working Papers or the papers in a single area, see instructions inside the back cover. A complete index of all NBER Working Papers may be accessed using our gopher server at nber harvardedu.

Number

4728

4730

4731

4732

4733

4734

4735

4736

4741

4742
Author(s)

Edward L. Gheser

David C. Maré

Jill $\mathrm{M}$. Constantine

David Neumark

Vermon Henderson

Lucian Arye Bebchuk

Howard F. Chang

Amanda Gosling

Stephen Machin

Richard Disney

Amanda Gosling

Stephen Machin

James M. Poterba

Kim S. Rueben

William Easterly

Stanley Fischer

Philippe Aghion

Olivier Jean Blanchard

Shang-Jin Wei

David C. Parsley

Shang-Jin Wei

Boyan Jovanovic

Yaw Nyarko

David G. Blanchflower

Richard B. Freeman

Martin Neil Baily

Eric J. Bartelsman

John Haltiwanger

Richard Dickens

Stephen Machin

Alan Manning
Title

$\underline{\text { Date }}$

Cities and Skills

$5 / 94$

Training and the Growth of Wage Inequality

$5 / 94$

Extemalities and Industrial Development

$5 / 94$

An Analysis of Fee-Shifting Based on the

$5 / 94$

Margin of Victory: On Frivolous Suits,

Meritorious Suits, and the Role of Rule 11

Trade Unions and the Dispersion of

Earnings in British Establishments, 1980-90

British Unions in Declines An Examination of the 1980s Fall in Trade Union Recognition

$5 / 94$

$5 / 94$

Myth $\propto$ Reality?
The Distribution of Public Seclor Wage Premia:

New Evidence Using Quantile Regression Methods

The Soviet Economic Decline: Historical

$5 / 94$

and Republican Data

On the Speed of Transition in Central Europe

$5 / 94$

Anticipations of Foreign Exchange Volatility and Bid-Ask Spreads

$5 / 94$

Insignificant and Inconsequential Hysteresis:

$5 / 94$

The Case of U.S. Bilateral Trade

The Bayesian Foundations of Learning by Doing

$5 / 94$

The Legacy of Communist Labor Relations

$5 / 94$

Downsizing and Productivity Growth:

$\$ / 94$

The Effects of Minimum Wages on Employment:

$5 / 94$

Theory and Evidence from the UK 
To order any of these papers, see instructions at the end of the list. To subscribe to all NBER Working Papers or the papers in a single area, see Instructlons Inside the back cover. A complete index of all NBER Working Papers may be accessed using our gopher server at aberharvardeda.

Number

4746
Author(s)

K.C. Chan

Wai-Ming Fong

René M. Stulz

Gordon H. Hanson

Douglas A. Irwin

Douglas R. Nelson

Bruce L. Gardner

Francine D. Blau Lawrence M. Kahn

Joseph P. Kalt

Jonathan Gruber

J. Michael Finger

Ann Harrison

Dan Ben-David

David H. Papell

Edward E. Leamer
Title

Date

Information, Trading and Stock Returns:

Lessons from Dually-Listed Securities

$5 / 94$

Localization Economies, Vertical

Organization, and Trade

$5 / 94$

Trade Politics and the Semiconductor Industry

$5 / 94$

The Political-Economy of U.S.

Automobile Protection

$5 / 94$

The Political Economy of U.S. Expart

Subsidies for Wheat

$5 / 94$

The Impact of Wage Structure on Trends in

$5 / 94$

U.S. Gender Wage Differentials: 1975-87

Precedent and Legal Argument in U.S. Trade

$5 / 94$

Policy: Do They Matter to the Political

Economy of the Lumber Dispule?

The Consumption Smoothing Benefits of

Unemployment Insurance

$5 / 94$

The MFA Paradox: More Prolection and More Trade?

$5 / 94$

The Great Wars, The Great Crash, and The

Unit Rool Hypothesis: Some New Evidence

$5 / 94$

About an Old Stylized Fact

American Regionalism and Global Free Trade

Copies of the above working papers can be obtained by sending $\$ 5.00$ per copy (plus $\$ 10.00$ per order for postage and handling for all locations outside the continental U.S.) to Woxting Papers, NBER, 1050 Massachusetts Avenue, Cambridge, MA 02138-5398. Advance payment is required on all orders. Payment may be made by check or credit card. Checks should be made payable to the NBER and must be in dollars drawn on a U.S. bank If paying by credit card, include the cardholder's name, account number and expiration dale. For all mail orders, please be sure to include your relurn address and telephone number. Woring papers may also be ordered by telephone $(617-868-3900)$, or by fax (617-868-2742). 


\section{National Bureau of Economic Research}

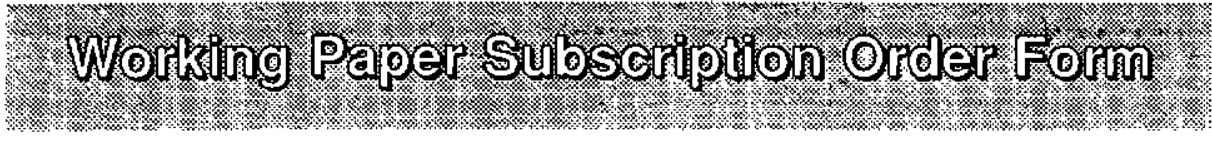

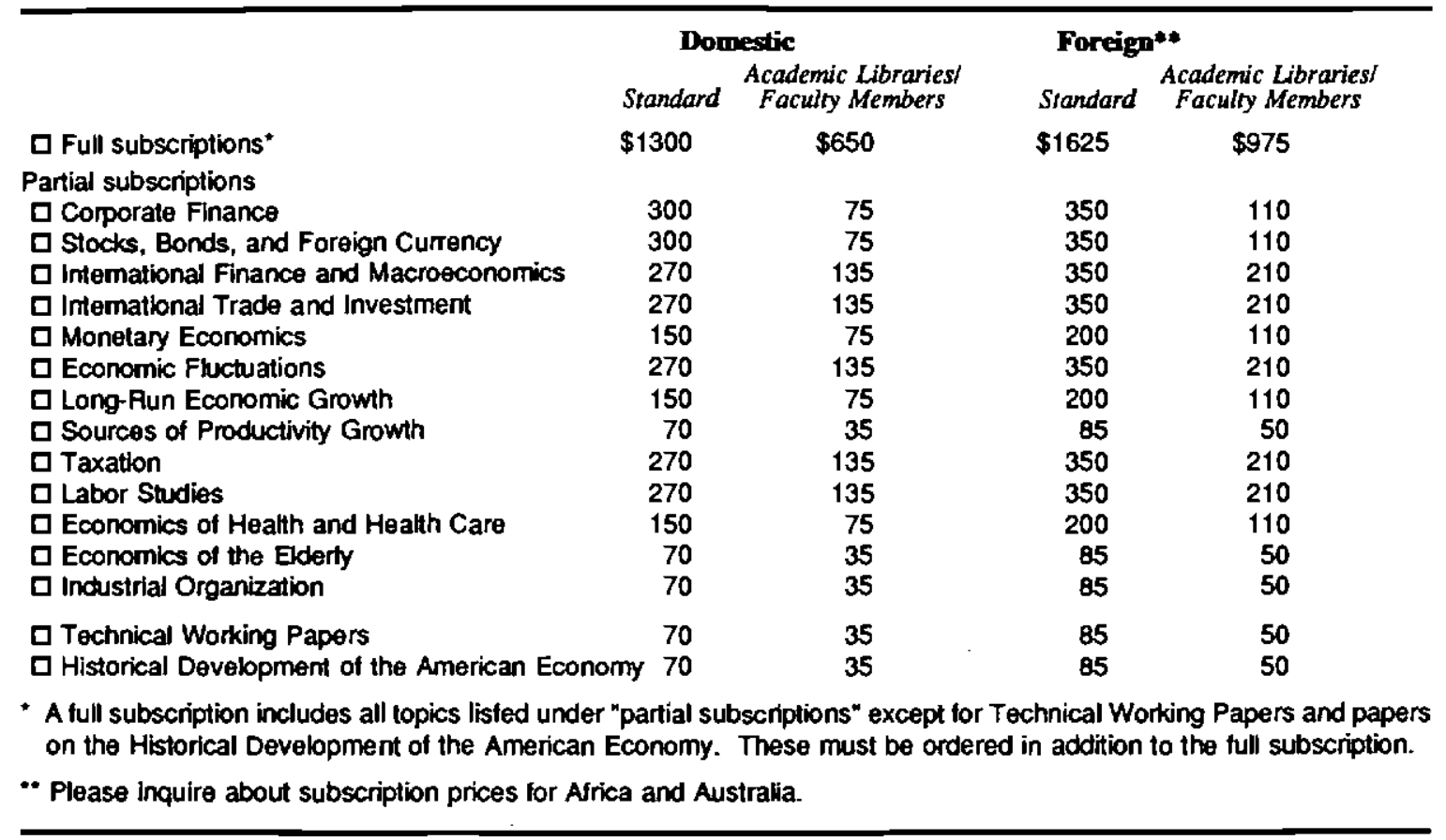

\section{PAYMENT OPTIONS}

YES! Please begin my subscription to the NBER Working Paper Series. I have indicated above which papers I would like to receive.

By Phone: (617) 868-3900

By FAX: (617) 868-2742

By Mail: Publications Department

National Bureau of Economic Research

1050 Massachusetts Ave.

Cambridge, MA 02138

$\square$ Payment in the amount of enclosed.

$\square$ Please charge my: $\square$ VISA $\square$ MasterCard

Card Number:

Card expiration:

Signature:
Please mail my papers to this address:

Name

Address

Phone:

FAX: 